\title{
SPORT-TOURISM INTERESTS IN THE LIGHT OF ALL THE INTERESTS OF PHYSICAL EDUCATION STUDENTS IN THE SELECTED ACADEMIES IN POLAND
}

\author{
Sport-tourism interests of the physical education students
}

\author{
ANNA BROJEK, ANNA BOCHENEK \\ The Josef Pilsudski University of Physical Education in Warsaw, Faculty of Physical \\ Education and Sport in Biała Podlaska, Department of Pedagogics
}

\begin{abstract}
Mailing address: Anna Brojek, Faculty of Physical Education and Sport, 2 Akademicka Street, 21-500 Biała Podlaska, tel.: +48 509111223, fax: +48 83 3428800, e-mail: ajbrojek@gmail.com
\end{abstract}

\begin{abstract}
Introduction. Children's and youth's interests are of great importance in the view of pedagogical science. It is an element of a human's personality which makes people take action and for endeavours to achieve particular aims. Material and methods. The method applied in the research was the diagnostic survey based on a questionnaire. The questionnaire used in the research was the Springer's Interests Questionnaire adopted by Cekiera and an open question like 'What are your interests?'. The survey was conducted in Academic Year 2008/2009 among 667 first-year physical education students of the first level of full-time studies in eight academies in Poland. Results. The conducted survey indicates that, among all the first-year physical education students' interests, there is a clear tendency for students to be interested in sport and tourism. The majority of respondents tends to be interested only in sport and tourism, they are defined as one-track mind students, and this can be proven through their deep and extensive knowledge in these subjects. The factors that significantly influence and differentiate the statistics of the survey were: sex, social background and place of residence. However, the type of school finished does not have an impact on the result of the survey since there is no connection between the finished school and interests. Conclusion. Owing to the fact that the majority of respondents definitely show a one-track mind interest in sport-tourism and care-education, it can be suggested that they tend to have the right qualities to be teachers of physical education.
\end{abstract}

Key words: interests, students, physical education, studies

\section{Introduction}

Children's and youth's interests are of great importance in the view of pedagogical science. It is an element of a human's personality which makes people take action and for endeavours to achieve particular aims. Not only do interests influence the progress in learning at school or the choice of our hobby, but they also determine the choice of studies, professions and the level of satisfaction we get from our work. In order to understand our children better, parents or legal guardians are advised to get to know their children's interests first. Thus, it allows them to implement the correct learning techniques and content of the learning materials so as to make the education and upbringing more natural. Being familiarized with the children's interests gives an opportunity to organize their free time in an effective way. This issue is becoming more significant nowadays since psychologists and pedagogues warn against the fact that the lack of abilities to organize children's free time contributes to social pathologies. Being familiarized with children's interests allows to organize attractive and constructive activities of spending free time [1].

As far as etymology is concerned, the word interest is of Latin origin. Originally, the word consists of two words 'interesse' meaning 'to be between'. Thus, in Polish we have a noun 'zainteresowanie', a verb 'być zainteresowanym' and adjective 'interesujący' [2].
Żebrowska [3] made an attempt to define the word interests, however, she claims that because of the fact that it is naturally associated with many aspects it is difficult to create a universal, one term that satisfies all researches. Curiosity, fancy and passion are the terms that highly reflect the word interests. Gurycka [4] shows the correlation between the words interests and curiosity so indicating that interest is a common manifestation of curiosity. Hence, curiosity is the fundamental element of interest. Passion, however, has a mental dimension and it shows a positive attitude towards some activities.

Gerstmann presents a different definition as he states that interest is 'a certain way of attention, thoughts and intentions that can be triggered by things connected with the emotional sphere. The interest induces a human's activity that is in accordance with his interests' [5]. It can be said that the interests have some motivating elements that shape people's personality and I do not mean motivation in general, but rather cognitive motivation that treats interest as a basic element and it is, as Mądrzycki states: 'a specific cognitive attitude, a tendency of paying attention for selective objects, intellectual readiness to be engaged in a specific activity, a pursuit of learning about the outward things' [6]. The author mentions the intensity of the interests that can be described as the frequency of cognitive actions in relation to the subject of interests or it can be seen as a consistent and persistent engagement in a specific activity regardless of the outer influences. 
The interests are specified on the basis of the durability, in other words, the length of time when the interest is still highit is believed that strong and general interests are more longlasting. Nevertheless, taking into account the number of interests we can specify the individual interests and on the basis of this criterion people can have:

1. one-track mind interests, concerns the interest of one domain;

2. two-tack mind interests, refers to interests of two different domains;

3. multi-track mind interests, relates to many domains but it is concentrated on the major one;

4. amorphous interests, in other words, of no particular kind or character, unstable [4].

The term of the interests, its origins and characteristics were described by many scientists, especially by psychologists and pedagogues. The issue has appeared in pedagogy studies many times and triggered a heated debate among scientists like Jan Amos Komeński, John Locke and Jean-Jacques Rousseau. Children's and youth's interests were the fundamental elements of interests in Dewey's and Claparede's pedagogic systems [3].

The aim of the research was to define the importance of sport-tourism interests in the light of all the interests of firstyear physical education students. Moreover, the aim of the research was to show the connection between the sport-tourism interests and the selected social-demographic characteristics of the respondents.

\section{Material and methods}

The survey was conducted in Academic Year 2008/2009 among 667 first-year physical education students of the first level of stationary studies in eight academies in Poland. The selection of academies was random. It was intended to obtain answers for the following questions:

1. How important are the sport-tourism interests in the light of all the interests of the respondents?

2. Do sex, social background, place of residence and type of school finished highly influence and differentiate the respondents' sport-tourism interests?

3. Do the respondents who have one-track mind interests in different domains indicate these domains in the informal answers?

The method applied in the research was the diagnostic survey based on a questionnaire. The questionnaire used in the research was both the Springer's Interests Questionnaire adopted by Cekiera [7] and an open question like 'What are your interests?'. The questionnaire consists of 96 questions that allows to define twelve groups of interests: humanistic, pure science, natural science, economics-law, technical, commercial, economy, sport-tourism, artistic, systematizing, management-organization, care-education. The respondent answer Yes or No which allows to define the level of the interests which can be: definitely one-track mind (7-8 positive answers), ambivalent (4-6 answers) and low (1-3 answers). Apart from defining the respondent's interests, the questionnaire allows to have a wide insight into the respondent's attitude to life. More than 60 positives answers prove that the respondent has a wide spectrum of interests and a positive attitude towards life values and morals. However, more than 60 negative answers indicates that the respondent keeps oneself at a distance, tends to isolate oneself, is in a negative frame of mind, has a narrow spectrum of interests and is pessimistic.

In the statistic paper of the material the following items were calculated: the average, the test chi-square value $\left(\mathrm{X}^{2}\right)$, the correlation value $\left(\mathrm{C}_{\mathrm{KOR}}\right)$. The accepted level of importance of the differences is $\mathrm{p}<0.05$.

\section{Results}

In order to define the importance of the sport-tourism interests in the light of all the respondents' interests an average rate of importance was calculated for each type of interest. Thus, it allowed to specify the place and the importance of each type of interest. The results show that the dominant interest among students is sport and tourism. Sport-tourism interests reached the highest rate (2.56) and it highly exceeds the rest of the types of interests. The care-education interests are assigned to second place with the result (2.10) and in third place is economy (1.96). The interest of the least popularity are: natural science, economics-law and artistic (Tab. 1).

Table 1. The average rate of importance of the respondents' interests

\begin{tabular}{|l|c|c|}
\hline \multicolumn{1}{|c|}{ Type of the interest } & $\begin{array}{c}\text { The average rate } \\
\text { of importance }\end{array}$ & Place \\
\hline Sport-tourism & 2.56 & 1 \\
\hline Care-education & 2.10 & 2 \\
\hline Economy & 1.96 & 3 \\
\hline Management-organization & 1.95 & 4 \\
\hline Pure science & 1.86 & 5 \\
\hline Systematizing & 1.84 & 6 \\
\hline Technical & 1.72 & 7 \\
\hline Commercial & 1.69 & 8 \\
\hline Humanistic & 1.63 & 9 \\
\hline Natural science & 1.59 & 10 \\
\hline Economisc-law & 1.43 & 11 \\
\hline Artistic & 1.39 & 12 \\
\hline
\end{tabular}

Moreover, the aim of the research was to show the connection between the sport-tourism interests and the selected socialdemographic characteristics of the respondents. The factors that significantly influenced and differentiated the result of the survey were: sex, social background and place of residence. However, there were no links between the type of school finished and their interests so it did not have an impact on the result of the survey. Men (63.4\%) have definitely one-track mind interests in sport and tourism, those of agricultural origins (74.4\%), those from the working class $(62.6 \%)$, those from rural areas $(65.8 \%)$ and those from towns $(62.9 \%)$. The correlation value $\left(\mathrm{C}_{\mathrm{KOR}}\right)$ indicates that there are no significant differences between the variables. When it comes to the connection between sport-tourism interests and sex and social background the correlation value is rather low (0.27) for sex and (2.25) for social background. As for the place of residence the correlation value is defined as weak (Tab. 2). 
Table 2. The connection between the level of sport-tourism interests and social-demographic variables

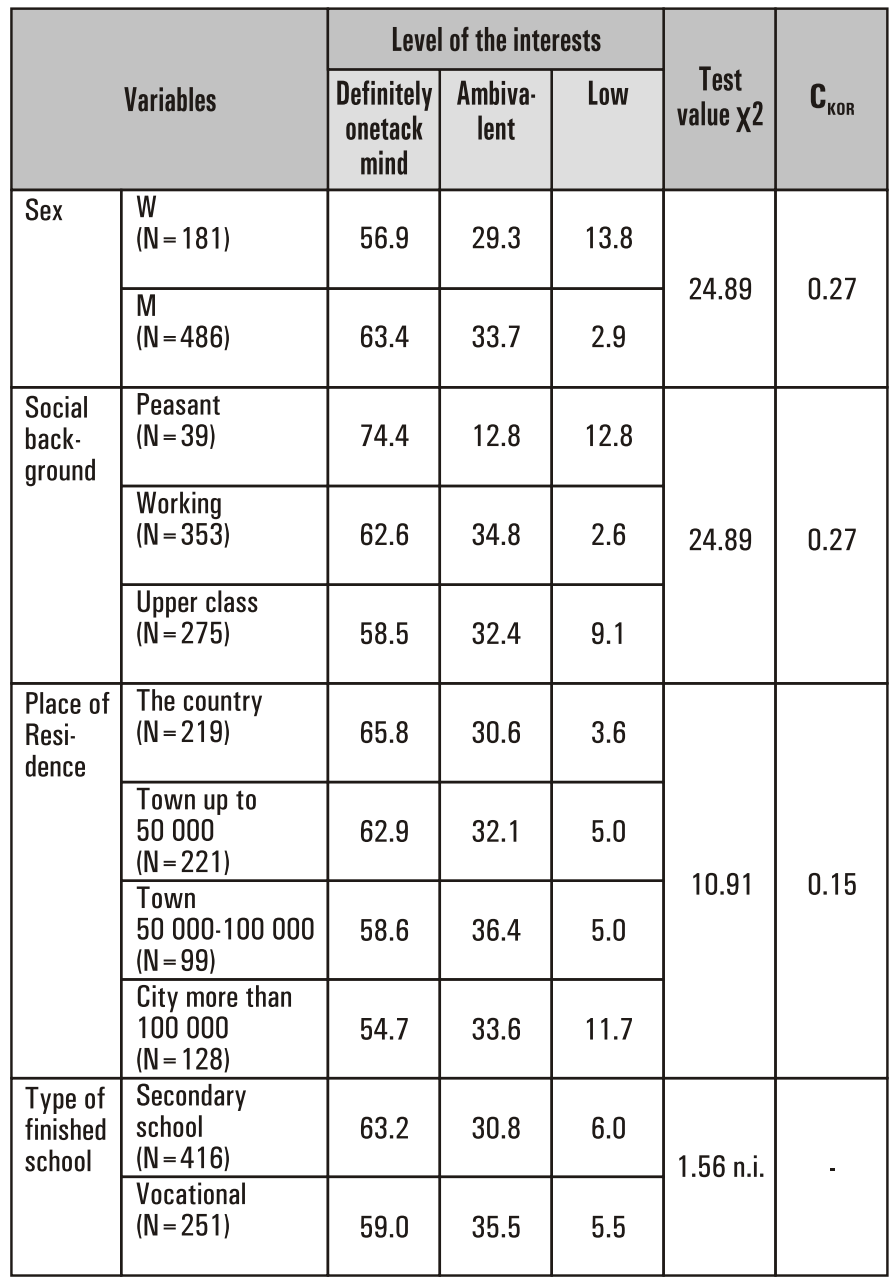

Due to the fact that sex turned out to be the variable that differentiated sport-tourism interest the most, other types of interests were analyzed in the context of this variable. It can be said that there is a vital link between sex and all the interests, with the exception of the artistic interests. The test value chi- square indicates that sex does not differentiate the artistic interests and the majority of respondents show a low interest in art. The correlation value allowed to state that sex is a statistic variable that differentiates humanistic, technical, systematizing, management-organizational, care-education interests. The correlation value between sex and each type of interest is average. The correlation value between sex and pure sciences, natural sciences, commerce and economy is low and as for economics-law the correlation is weak (Tab. 3).

The level of the respondents' interests was defined on the basis of the Interests Questionnaire. Having analyzed the answers from the open question 'What are you interests?' we have a deeper insight into the research issue. The respondents' answers were categorized as in the Spranger's Questionnaire. In the figure, there are interests mentioned by the students and also the ones that are one-track interests. Having analyzed the answers, it can be said that the answers were similar. The significant differences appeared only in two types of interests since the one-track mind interests in sport and tourism were stated by $64.4 \%$ of the respondents but first $85.2 \%$ of respondents declared to have them. The second discrepancy concerned the care-education interests that were stated by $30.0 \%$ of respondents but first $8.1 \%$ of the respondents declared to have them (Fig. 1).

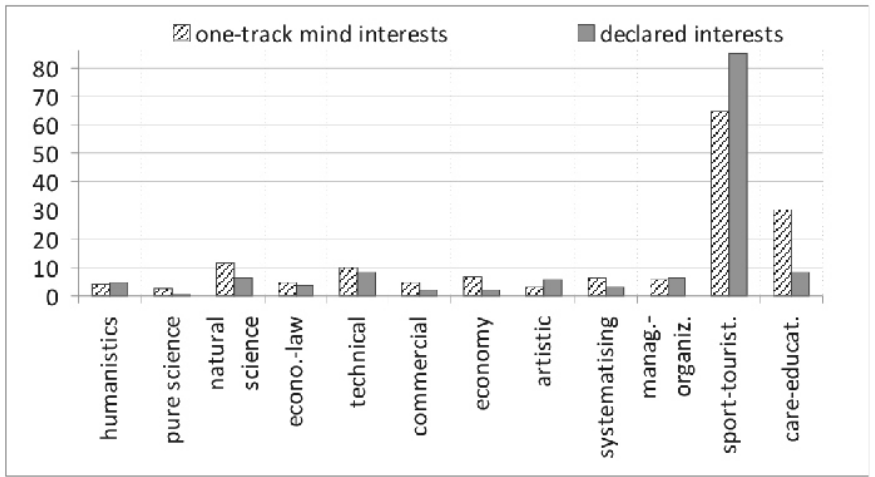

Figure 1. One-track mind interests and the declared interests

Table 3. The sex of the respondent and the level of interest

\begin{tabular}{|c|c|c|c|c|c|c|c|c|}
\hline \multirow{3}{*}{ Types of interests } & \multicolumn{6}{|c|}{ The level of interests } & \multirow{3}{*}{$\begin{array}{c}\text { Test value } \\
x^{2}\end{array}$} & \multirow{3}{*}{$\mathbf{C}_{\text {кOR }}$} \\
\hline & \multicolumn{2}{|c|}{ Definitely one-track mind } & \multicolumn{2}{|c|}{ Ambivalent } & \multicolumn{2}{|c|}{ Low } & & \\
\hline & K & M & K & M & K & M & & \\
\hline Humanistic & 24.9 & 3.5 & 60.8 & 37.6 & 14.3 & 58.9 & 140.25 & 0.55 \\
\hline Pure Science & 8.8 & 29.4 & 43.1 & 36.0 & 48.1 & 34.6 & 36.16 & 0.30 \\
\hline Natural Science & 19.3 & 7.2 & 38.7 & 37.6 & 42.0 & 55.2 & 21.08 & 0.23 \\
\hline Economics-law & 13.8 & 7.6 & 38.1 & 19.6 & 48.1 & 72.8 & 12.68 & 0.18 \\
\hline Technical & 5.5 & 25.3 & 16.0 & 37.9 & 78.5 & 36.8 & 98.65 & 0.47 \\
\hline Commercial & 9.4 & 15.4 & 55.8 & 36.0 & 34.8 & 48.6 & 21.38 & 0.23 \\
\hline Economy & 32.6 & 19.1 & 43.1 & 33.5 & 24.4 & 47.4 & 31.89 & 0.28 \\
\hline Artistic & 4.4 & 3.1 & 33.7 & 31.7 & 61.9 & 65.2 & 1.04 ni. & - \\
\hline Systematizing & 53.0 & 18.1 & 31.5 & 29.0 & 15.5 & 51.9 & 102.22 & 0.48 \\
\hline Management-Organizational & 12.1 & 42.2 & 17.1 & 30.2 & 70.8 & 27.6 & 107.69 & 0.49 \\
\hline Care-education & 61.9 & 28.4 & 28.1 & 37.9 & 9.4 & 33.7 & 74.33 & 0.42 \\
\hline
\end{tabular}




\section{Discussion}

The interests are claimed to be a complicated mental process where there is a strong link between cognitive and emotional consciousness. The cognitive processes in the interests are clearly concentrated around the specific domains of life. They can be part of the natural environment, the society or certain elements of their lives and development. They also focus on the individual, their psychological life, and the attitude towards others. Thus, interests are specific elements of the humans' personality which makes people take action and for endeavours to achieve particular aims [8]. It is vital to have versatile interests while studying. A student should be interested in a wide spectrum of issues not only in the obligatory subject at studies. A student should show interest in the basic domains of life that broaden one's mind such as social affairs, economics, economy issues, artistic and interests connected with their future profession $[9,10]$. The research proves the tendency mentioned above. The respondents tend to have sport-tourism and careeducation interests which are in accordance with the preferences suitable for the future teachers of physical education. Additionally, they have humanistic, artistic, managementorganizational and technical interests which broaden their minds.

The next issue discussed in the research was the influence of social-demographic factors on the level of the respondents' interests. It turned out that sex, social background and place of the residence statistically influence the respondents' interests. The results of the research only partially confirmed the previous analysis $[11,12]$, however, they are in accordance with Sankowski's opinion [13]. Suffice to mention that between sex and humanistic and care-education interests is the most noticeable connection which is not confirmed by Kałużny [14].

The subject of the interests are human activities e.g. sport, tourism, recreation. They trigger cognitive processes that are useful in gaining knowledge required at studies [14, 15]. The previous Gracz's [16] and Sankowi's [13] research indicated the link between the type of graduated school and interests. However, according to respondents, the type of school does not differentiate considerably the level of their sport-tourism interests.

\section{Conclusions}

1. The sport-tourism interests are the leading interests in the light of all the interests of first-year physical education students. The majority of them have a one-track mind interest in sport and tourism which proves their engagement in this domain of life.

2. The variables that significantly influenced and differentiated the result of the survey were: sex, social background and place of residence of the respondents. However, no link between the type of school finished and interests was stated.

3. It can be said that there is a vital connection between sex and all of the interests, with the exception of the artistic interests. The most noticeable connection was observed between sex and humanistic, technical, systematizing, management-organizational, care-education interests. The high rate of definitely one-track mind interests in care and education proves that the respondents have the suitable predisposition for the future profession of a physical education teacher.

\section{Acknowledgements}

The research was accomplished within the framework of the research project of Faculty of Physical Education and Sport in Biała Podlaska, Josef Pilsudski University of Physical Education in Warsaw - BW.III/10 - financed by Ministry of Science and Higher Education.

\section{Literature}

1. Baley, S. (1996). Outline of Educational Psychology. Warsaw: PWN. [in Polish]

2. Tobiasz-Adamczyk, B. (1998). Selected Elements of Sociology of Health and Disease. Cracow: Pub. UJ. [in Polish]

3. Żebrowska, M. (1982). Developmental Psychology of Children and Youth. Warsaw: Pub. PWN. [in Polish]

4. Gurycka, A. (1978). Development and Shaping of the Interests. Warsaw: Pub. WSiP. [in Polish]

5. Gerstmann, S. (1968). Character. The Selected Psychological Issues. Warsaw: Pub. PZWS. [in Polish]

6. Mądrzycki, T. (1996). Character as the System Creating and Realizing the Plans. Gdańsk: Pub. PTP. [in Polish]

7. Cekiera, Cz. (2001). The Addiction Risk. Lublin: Pub. TN KUL. [in Polish]

8. Buczek, A. (2009). The Research Interests of Academic Students. Poznań: Pub. The School of Higher Education in Security. [in Polish]

9. Skicka-Kortus, J. (1987). Attempt to define the characteristics of tourism and recreation students' interests. Roczniki Naukowe AWF Poznań 36, 57-59. [in Polish]

10. Elbanowska-Ciemuchowska, S. (2010). Youth's Interests in Pure Science. The Diagnosis of the Issue of Interests of the Selected Age Groups and the Propositions of Shaping. Warsaw: Pub. Warsaw University. [in Polish]

11. Krzywoń, D. (2009). Sex and professional preferences and interests. Zeszyty Naukowe Wyższej Szkoły Humanitas 4, 55-65. [in Polish]

12. Bańkosz, Z. \& Dąbrowski T. (2009). Player's interests and the sport knowledge and the efficiency of the table tennis game. Rozprawy Naukowe AWF Wrocław 28, 367-371. [in Polish]

13. Sankowski, T. \& Konys L. (2004). Did the social changes influence the physical education students' interests? In M. Mikołajczyk (Ed.), Psychological Correlation Between the Physical Activity and the Sport Success: Based on the Sportsmen's and Physical Education Students' Character (pp. 153-162). Warsaw: PTNKF. [in Polish]

14. Kałużny, K. (2010). Different types of physical activity interests of junior high school students. Rozprawy Naukowe AWF Wrocław 30, 212-217. [in Polish]

15. Sankowski, T. \& Stachowiak K. (2006). Interests as the reason for learning in physical education and sport. Kultura Fizyczna 3-4, 13-16. [in Polish]

16. Gracz, J. \& Walczak M. (2000). Learning successes and the interests of tourism and recreation students. Roczniki Naukowe AWF Poznań 47-48, 15-35. [in Polish]

Submitted: November 7, 2011

Accepted: December 27, 2011 